\title{
SOME POLICY IMPLICATIONS OF LABOR MOBILITY \\ IN THE SOUTH WITH SPECIAL REFERENCE TO THE
}

TENNESSEE VALLEY REGION: COMMENT

\section{Kimon J. Constas}

The study by Matson and Smith presents a picture of important labor adjustments seldom seen in economic journals. To analyze these adjustments we must go back to our price theory, where the demand for an input is a derived demand, competition between inputs is possible, and human capital includes education, training, and information. The authors are candid about their problems and present sufficient data for critics tofreelydraw conclusions from the study's text.

The main concern of Matson and Smith is the labor force response to economic development in the Tennessee Valley region between 1957 and 1965. Virtually all of the period's interesting issues and the interpretive questions flow from the reading of the data collected.

My first comment comes from the following statement:

"Importation of labor is expensive and often in conflict with developmental objectives related to better utilization of the resident labor force."

The reader thus senses that importation of labor is a bad thing since it is expensive and incompatible with the full employment goal of the region under review. But laboris imported as a consequence of prevailing significant wage-differentials and/or lack of specific skills in the region. In the long-run importation of labor will reduce the wage-ratedifferentials of particular skills, and, thus, the region will not be hurt. Finally, if skilled labor is not available, importation of labor and unemployment a re compatible.

My second comment, is that, the authors neither distinguish labor by skill category (e.g. salaried personnel and skilled, semiskilled and unskilled labor) nor analyze the relationship between capital stock and labor. As a consequence, no light is cast on the changes in the labor-mix over time.

Economists may well wish to reflect on some problems for which the authors give no answers. What caused the sizable interindustry shifts of labor to high-wage manufacturing? Which skills left high-wage manufacturing? Which skills left high-wage manufacturing for medium and low-wage activities? Have changes occurred in the capital stock of the various industries to make it more complementary to skilled labor than to less skilled labor, and in consequence, to cause less-skilled labor to outmigrate? What is the elasticity of substitution of labor and capital in high-, medium-, and lowwage manufacturing in Tennessee?

Another problem lies in the interpretation of the data. The authors report that high-wage manufacturing workers were found to be much more "stable" than other manufacturing workers. Moreover, the incidence of multiple jobholders was high in low and medium-wage manufacturing. However, by 1965 the percentage change in the proportion of high-wage manufacturing workers holding more than one job was $83.3 \%$, of medium-wage $31.5 \%$, and of low-wage $40 \%$. I think the above trends do not indicate that high-wage manufacturing workers are more "stable" than other manufacturing workers. On the contrary, they indicate that high-wage manufacturing experienced a change in its skill-mix, because, say, of new capital stock installed so that 
more semi-skilled workers and fewer unskilled workers were required than before. These changes in the skill-mix may explain why high-wage manufacturing was both exporting and importing wage earners. Next, the rise in the proportion of multiple jobholders in high-wage manufacturing may indicate that the earnings of the unskilled workers did not adjust fast enough to those of skilled-and semi-skilled workers, as a result, presumably, of the elastic supply of unskilled workers. Hence, low-wage earners in high-wage manufacturing had to hold many jobs.

My final remark concerns the finding that the 1957 incomes of all categories of outmigrants were lower than those of nonmovers. This is interesting, but the authors say little about the economic and social characteristics of the outmigrants. I turn therefore back to the topic of "human capital." In a study of 430 families in Epirus, a Greek agricultural province, families with migrants were found to have fewer assets, more family members, lower income, and a lower index of education than families without migrants. This means that if education is regarded as a stock of capital with positive future yield, then the more education one gets, the wealthier one is, and the less will be one's inclination to emigrate. This suggests what is in fact the case, that Tennessee did not lose humancapital. Actually, the authors state that the region exported less-skilled workers and unknown numbers of workers without job experience. 


\section{FOOTNOTES}

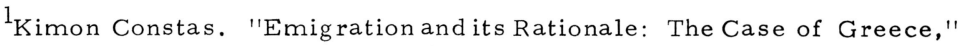
paper presented at the lst Canadian Conference in Applied Statistics, Montreal, May 1971. 